http://jmscr.igmpublication.org/home/ ISSN (e)-2347-176x ISSN (p) 2455-0450 crossref DOI: https://dx.doi.org/10.18535/jmscr/v7i8.136

Research Article

\title{
Sustainability of immune response to Hepatitis B Virus vaccination 3 years post vaccination among HIV-1 infected and uninfected adults in Kenya
}

\author{
Authors
Rose Kamoni $^{*}$, Kenneth Ngure $^{2}$, Elizabeth Irungu ${ }^{3}$, Nelly Mugo ${ }^{4}$, \\ Bhavna Chohan ${ }^{5}$, Caroline Ngugi ${ }^{6}$
}

${ }^{1}$ Institute of Tropical Medicine and Infectious Diseases, Jomo Kenyatta University of Agriculture and Technology, Kenya. P. O BOX 62000-00200, City square, Nairobi, Kenya. School of Medicine, University of Nairobi, P. O BOX 30197, GPO, Nairobi, Kenya

${ }^{2}$ Department of Community Health, College of Health Sciences, Jomo Kenyatta University of Agriculture and Technology, Kenya. P. O BOX 62000-00200, City square, Nairobi, Kenya

${ }^{3}$ Centre for Clinical Research, Kenya Medical Research Institute. P .O BOX 54840-00200, Nairobi, Kenya

${ }^{4}$ Centre for Clinical Research, Kenya Medical Research Institute. P .O BOX 54840-00200, Nairobi, Kenya

${ }^{5}$ Centre for Virus Research, Kenya Medical Research Institute. P .O BOX 54840-00200, Nairobi Kenya.

Department of Global Health, Box 359909, University of Washington, Seattle, WA

${ }^{6}$ Department of Medical Microbiology, College of Health Sciences, Jomo Kenyatta University of

Agriculture and Technology, Kenya. P. O BOX 62000-00200, City square, Nairobi, Kenya

*Corresponding Author

Rose Wanjiku Kamoni

Institute of Tropical Medicine and Infectious Diseases, Jomo Kenyatta University of Agriculture and Technology, Kenya. P. O BOX 62000-00200, City square, Nairobi, Kenya. School of Medicine, University of Nairobi, P. O BOX 30197, GPO, Nairobi, Kenya

Abstract
Background: Hepatitis B virus (HBV) infection, a leading cause of chronic hepatitis, liver cirrhosis, and
hepatocellular carcinoma worldwide is preventable by vaccination. Completion of recommended vaccination over
$90 \%$ of adults develops protective anti-Hbs antibodies levels. However, there's paucity of data on sustained
immune response to HBV vaccine among HIV infected African adults. A retrospective study was conducted and
analysed 336 archived serum samples collected 3 -years post HBV vaccination from participants enrolled in the
Partners PrEP study, for Hepatitis B surface antibody (anti-Hbs) using ELISA.Samples that didn't have protective
anti-Hbs titers were further tested for Hepatitis B surface antigen (HBsAg). Univariate logistic regression was used
to determine factors associated with non-response. Of the 336 samples tested, 176 (52.4\%) were from HIV-1
infected, 40 (22.7\%) were male. 160 samples from HIV-1 uninfected, 125 (78.1\%) were male. The mean (standard
deviation) age of the study population was 34.6 (8.5) years. Of the 62 (18\%) who didn't have protective anti-Hbs
titers, 50 (81\%) were HIV-1 infected. HIV infected were more likely to have less protective anti-Hbs titers
(p<0.001) compared to HIV uninfected. Compared to men, women were more likely not to have protective anti-Hbs
levels (11.5\% vs. 25.1\%, p=0.002). Seven (11.3\%) of the 62 samples that didn't have protective anti-Hbs titres,
also tested positive for HBsAg, all were HIV-1 infected. More than a quarter of HIV infected vaccinated against
HBV didn't have protective anti-Hbs titres, some acquired HBV infection. Regular testing for immune response to
HBV vaccination among HIV infected should be considered.
Keywords: Hepatitis B Virus, Vaccine, HIV-1 infection, Kenya.




\section{Introduction}

Hepatitis B virus (HBV) infection, a leading cause of chronic hepatitis, liver cirrhosis, and hepatocellular carcinoma worldwide, is more common among HIV-infected individuals due to shared risk factors for viral acquisition ${ }^{(1)}$. Current statistics estimate that $10 \%$ of 34 million HIVinfected patients have concurrent chronic HBV infection $^{(3)}$. Prevalence and incidence of $\mathrm{HBV}$ infection among HIV-infected patients varies widely based on the risks for HIV and HBV transmission, implementation of $\mathrm{HBV}$ vaccination programs, and the geographic regions with different levels of endemicity of HBV infection in the general population $^{(1,4)}$. Even so, Africa which has the highest HIV-1 disease burden globally has high endemicity for HBV infection with 50 million of the 360 million people infected with HBV worldwide living in Africa ${ }^{(5)}$.

Countries in Asia and sub-Saharan Africa have high HBV endemicity with vertical and early childhood exposure being the most common modes of transmission respectively; similarly the prevalence of HBV among HIV-infected individuals in these areas is higher at an estimated $20-30 \%{ }^{(5)}$. Studies have reported that men infected with both HIV and HBV have liver-related mortality that is eight times higher than that in men with HIV alone and 17 times higher than in those with HBV alone ${ }^{(4)}$. This is because HIV infection adversely affects all phases of HBV infection by increasing the risk of chronic infection, decreasing the rate of hepatitis B e-antigen clearance, increasing virus replication, accelerating the loss of $\mathrm{HBsAb}$, and increasing the risk for cirrhosis and hepatocellular carcinoma ${ }^{(8)}$.Vaccination is the best method of prevention against $\mathrm{HBV}$ and following complete immunization more than $95 \%$ of infants and children and more than $90 \%$ of adults achieve protective anti-Hbs titres greater than $10 \mathrm{mIU} / \mathrm{mL}^{(9)}$. International guidelines released by the National Institutes of Health (NIH), Centers for Disease Control and Prevention (CDC), HIV Medical Association and the US Advisory Committee on Immunization Practices in the United states and the European AIDS Clinical Society and the British HIV Association in Europe ${ }^{(10,11)}$ recommend that all individuals with HIV who are susceptible to HBV should be vaccinated with the 3 dose primary vaccine series given during a 6 month period $^{(4,13)}$. Studies done in high income countries on $\mathrm{HBV}$ vaccination have suggested that compared to HIV uninfected persons, HIV infected persons have diminished responses to $\mathrm{HBV}$ vaccination. One study found that $20 \%-70 \%$ of HIV-infected persons developed an immune response to $\mathrm{HBV}$ vaccination $^{(14)}$. A US-based HIV outpatient study reported that only $37 \%$ of eligible HIV infected patients who completed the vaccination series achieved protective antibody titers ${ }^{(12)}$. A study conducted among HIV infected adults in Kenya found that non response to HBV vaccine at one year post vaccination was higher among HIV infected participants, compared to HIV uninfected participants and revaccination of initial nonresponders resulted in a higher overall response to revaccination ${ }^{(5)}$. Data from low-income countries for determination of long-term immune protection of HBV vaccine in adults are few. This study aimed to compare the levels of HBV antibody titers in both HIV infected and HIV uninfected adults in Kenya, 36-month post $\mathrm{HBV}$ vaccination and also determine incident Hepatitis B infection, among individuals with low-levels of protective antibodies postvaccination.

\section{Materials and Methods Study population}

This was a retrospective study conducted among HIV infected and HIV uninfected men and women attending a research clinic in Thika, Kenya who took part in the Partners PrEP Study ${ }^{(15)}$. In brief, the Partners PrEP Study was a phase III, multisite, randomized, double blind, and placebo controlled trial of daily oral tenofovir-based pre-exposure prophylaxis (PrEP) for the prevention of HIV acquisition. All participants were members of heterosexual HIV serodiscordant couples (i.e. couples in which one member was HIV seropositive and the other seronegative) in which the HIV infected partner did not meet national guidelines for 
initiation of antiretroviral therapy and the HIV uninfected partners were healthy, with normal renal, liver and haematological function. They were randomized to daily oral tenofovir, emtricitabinetenofovir, or matching placebo with monthly follow-up for 36 months ${ }^{(15)}$.

\section{Sampling procedures}

Stored serum samples obtained 36 months post vaccination from participants, who had developed a positive antibody response either during initial vaccination and/or after revaccination were retrieved and thawed ${ }^{(5)}$

\section{Hepatitis B surface antibody and antigen ELISA}

We analysed 336 archived serum samples. As part of screening procedures for the Partners PrEP Study, all potential trial participants were assessed for HBV by use of HBV surface antigen (HBsAg; Murex Abbot Murex, Dartford). Study participants who tested negative to presence of HBsAg and $\mathrm{HBs} \mathrm{Ab}$ were offered vaccination with 3 doses of 20 $\mu \mathrm{g}$ recombinant HBsAg (Euvax B [LG Life Sciences, Seoul, Korea], Revacc B [Bharat Biotech International, India], or Shanvac B [Shantha Biotech, India], depending on supplier availability) at 0,1 to 3 , and 6 months.

All the 336 samples were tested for presence of anti-Hbs titre using enzyme linked immune absorbent assay (ELISA) (DiaSorin LIAISON antiHBs II assay, Italy) kit. In this, a sandwich ELISA involving primary and secondary anti-HBV were used to detect antibodies against hepatitis B surface antigen (anti-Hbs) in serum. Hundred (100) micro liters $(\mu 1)$ of incubation buffer was assigned into micro Elisa wells except for the blank well. $100 \mu \mathrm{l}$ of undiluted samples were added into to the designated wells after dispensing the Control and Calibrators and incubated at 37 degrees Celsius for 120 minutes. Washing was done using the phosphate buffer for five times and hundred (100) $\mu 1$ of the working enzyme tracer solution was added into each well except the blank well and incubated at 37 degrees Celsius for 60 minutes. Second washing was done using the phosphate buffer for five times and $100 \mu \mathrm{l}$ chromogen/substrate solutions was added into each well. The plate at this point was incubated at 37 degree Celsius for 30 minutes at room temperature, away from direct light. Thereafter the reaction was stopped by adding sulfuric acid into each well and the plates were read at $450 \mathrm{~nm}$ wavelength. Sixty two samples that had levels of anti-Hbs antibody titres less than 10 $\mathrm{mIU} / \mathrm{ml}$, were further tested for Hepatitis Surface antigen (HBsAg). It was done with an ELISA technique, using the HBsAg; Murex Abbot Murex, Dartford, (United Kingdom), kit. In this, a sandwich ELISA involving primary and secondary anti-HBV were used to detect HBV surface antigen in serum. Twenty five (25) micro liters $(\mu \mathrm{l})$ of specimen diluents was assigned into micro Elisa wells. $75 \mu 1$ of undiluted sample was added and incubated at 37 degrees Celsius for 60 minutes. Fifty (50) $\mu$ l of the conjugate solution was added into each well and incubated at 37 degrees Celsius for 30 minutes. Washing was done using the phosphate buffer for five times and $100 \mu$ substrate solution added into each well. The plate at this point was incubated at 37 degree Celsius for 30 minutes. Thereafter the reaction was stopped by adding sulfuric acid into each well and the plates were read at $450 \mathrm{~nm}$ wavelength.

Antibody titers were reported as dichotomous positive/negative with titers $<10 \mathrm{mlU} / \mathrm{ml}$ being considered negative. Similarly, HBsAg results were reported as dichotomous positive/negative with those that tested positive for presence of $\mathrm{HBsAg}$ being interpreted as HBV infected.

\section{Statistical analysis}

Baseline factors associated with non response to HBV vaccination were assessed using univariate logistic regression methods. The variables evaluated included sex, education, age, income, BMI and alcohol use. Data analysis was done using STATA ${ }^{\circledR}$ version 13 software. All statistical tests were interpreted at $5 \%$ level of significance.

\section{Ethical considerations}

Approval to conduct the study was granted by the Kenyatta National Hospital-University of Nairobi Ethical Review Committee, approval no.P685/11/2014. The Partners PrEP study was approved by the institutional review boards of the 
University of Washington and Kenyatta National Hospital, approval no. P322/10/2007.

\section{Results}

Of the 336 serum samples analysed, 176 (52.4\%) were from HIV infected participants and of those $136(40.5 \%)$ were female. The mean (standard deviation [SD]) age of the study participants was 34.6 (8.5) years. The mean (SD) CD4 cell count for the HIV infected participants was 526 (243) cells/ $\mu \mathrm{L}$ (Table 1$)$.

Factors associated with less anti-Hbs titres in circulation 36 months' post vaccination

At 36-months post HBV vaccination, 274 (81.5\%) participants had protective levels $(>10 \mathrm{mIU} / \mathrm{ml})$ of anti-Hbs antibody in the blood, while 62 (18.5\%) had levels of anti-Hbs antibody titres less than 10 $\mathrm{mIU} / \mathrm{ml}$. Of the participants with $<10 \mathrm{mIU} / \mathrm{ml}$ titres, 50 (80.7\%) were HIV infected and 43 (69.4\%) were female. HIV infected persons compared to HIV uninfected were more likely to have a non-response to $\mathrm{HBV}$ vaccination at 3 years post vaccination $(28.4 \%$ vs $7.5 \%, \mathrm{OR}=4.9,95 \% \mathrm{CI}$
2.5, $9.6 \mathrm{p}<0.001$ ). (Table 2). Similarly, compared to men, women were more likely to have low anti-Hbs titres $(11.5 \%$ vs $25.1 \%$, OR 2.58 , 95\% CI 1.43 , 4.66, $\mathrm{p}=0.002$ ). Among HIV infected participants, those with CD4 count greater than 500 cells/ $\mu \mathrm{L}$ were less likely to have low titres compared to those with less than 500 cells $/ \mu \mathrm{L}(20.8 \%$ vs $34.3 \%$, OR = $0.5,95 \%$ CI $0.25,0.99, \mathrm{p}=0.048$ ).

\section{Factors associated with positive HBsAg}

Of the 62 serum samples that tested low for antiHbs titers, seven (11.3\%) participants tested positive for presence of HBsAg. All samples testing positive for HBsAg were for HIV infected participants, six were female and four were aged greater than 30 years. Participants with any monthly income, compared to those with none were less likely to test positive for HBsAg (4.8\% vs $25.0 \%$, OR $0.15,95 \%$ CI 0.03, 0.86, $\mathrm{p}=0.03$ ). (table 3). Baselines, CD4 count, gender, years of education and age were not associated with increased risk of acquisition of Hepatitis B infection.

Table 1: Participants baseline demographic characteristics

\begin{tabular}{|c|c|c|}
\hline $\begin{array}{l}\text { Characteristics } \\
\mathrm{N}(\%) \text { or mean }(\mathrm{SD})\end{array}$ & HIV infected $(\mathrm{n}=176)$ & $\begin{array}{l}\text { HIV uninfected } \\
\quad(\mathrm{n}=160)\end{array}$ \\
\hline Age & $33.32(8.17) 7) .17)$ & $35.91(8.61)$ \\
\hline Sex, female & $136(77.27)$ & $35(21.88)$ \\
\hline $\begin{array}{l}\text { Number of children } \\
\text { At least one child }\end{array}$ & $161(91.5)$ & $136(85)$ \\
\hline \multirow{2}{*}{$\begin{array}{l}\text { Years of education } \\
\text { Less than } 8 \text { years } \\
>=8 \text { years }\end{array}$} & $58(33)$ & $65(40.6)$ \\
\hline & $118(67)$ & $95(59.4)$ \\
\hline \multirow{4}{*}{$\begin{array}{l}\text { Monthly income } \\
<=1000 \\
\quad \text { Between 1001-5000 } \\
\text { Between 5001-10000 } \\
>10000\end{array}$} & $81(46)$ & $38(23.8)$ \\
\hline & $61(34.7)$ & $83(51.9)$ \\
\hline & $21(11.9)$ & $24(15)$ \\
\hline & $13(7.4)$ & $15(9.4)$ \\
\hline $\begin{array}{l}\text { Alcoholic drinks per week } \\
\text { No alcohol use }\end{array}$ & $165(93.8)$ & $141(88.1)$ \\
\hline \multicolumn{3}{|l|}{ BMI } \\
\hline$<18.5$ & $28(8.3)$ & $14(4.2)$ \\
\hline $18.5-24.9$ & $100(29.8)$ & $116(34.5)$ \\
\hline $25.0-29.9$ & $22(6.5)$ & $35(10.4)$ \\
\hline$>30.0$ & $10(3.0)$ & $11(3.3)$ \\
\hline CD4 count & $526.24(243.45)$ & \\
\hline
\end{tabular}


Table 2: Factors associated with less anti-Hbs titres in circulation 36 months' post vaccination

\begin{tabular}{|c|c|c|c|c|}
\hline $\begin{array}{l}\text { Characteristics } \\
\mathrm{N}(\%) \text { or mean }(\mathrm{SD})\end{array}$ & $\begin{array}{l}\text { HBsAb positive } \\
\quad(\mathrm{n}=274)\end{array}$ & $\begin{array}{l}\text { HbsAb } \\
\text { Negative } \\
(\mathrm{n}=62)\end{array}$ & $\begin{array}{c}\text { OR } \\
(95 \% \mathrm{CI})\end{array}$ & $\mathrm{P}$ value \\
\hline $\begin{array}{l}\text { HIV status } \\
\begin{array}{l}\text { Uninfected } \\
\text { Infected }\end{array} \\
\end{array}$ & $\begin{array}{l}148(92.5 \%) \\
126(71.6 \%)\end{array}$ & $\begin{array}{c}12(7.5 \%) \\
50(28.4 \%)\end{array}$ & $\begin{array}{c}\text { Ref } \\
4.9(2.5,9.6)\end{array}$ & $<0.001$ \\
\hline $\begin{array}{l}\text { Male } \\
\text { Female }\end{array}$ & $\begin{array}{l}146(88.5 \%) \\
128(74.9 \%)\end{array}$ & $\begin{array}{l}19(11.5 \%) \\
43(25.1 \%)\end{array}$ & $\begin{array}{c}\text { Ref } \\
2.58(1.43,4.66)\end{array}$ & 0.002 \\
\hline $\begin{array}{c}\text { Age (years) } \\
18-30 \text { years } \\
>30 \text { years }\end{array}$ & $\begin{array}{c}84(78.5 \%) \\
190(83.0 \%)\end{array}$ & $\begin{array}{l}23(21.5 \%) \\
39(17.0 \%)\end{array}$ & $\begin{array}{c}\text { Ref } \\
0.75(0.42,1.33)\end{array}$ & 0.33 \\
\hline $\begin{array}{l}<18.5 \\
18.5-24.9 \\
25.0-29.9 \\
>30\end{array}$ & $\begin{array}{c}35(83.3 \%) \\
176(81.5 \%) \\
47(82.5 \%) \\
16(76.2 \%)\end{array}$ & $\begin{array}{c}7(16.7 \%) \\
40(18.5 \%) \\
10(17.5 \%) \\
5(23.8 \%)\end{array}$ & $\begin{array}{c}\text { Ref } \\
1.14(0.47,2.274) \\
1.06(0.37,3.07) \\
1.56(0.43,5.68)\end{array}$ & $\begin{array}{l}0.78 \\
0.91 \\
0.50\end{array}$ \\
\hline $\begin{array}{r}\text { CD4 (cells/ml) } \\
<500 \\
>500\end{array}$ & $\begin{array}{l}65(65.7 \%) \\
61(79.2 \%)\end{array}$ & $\begin{array}{l}34(34.3 \%) \\
16(20.8 \%)\end{array}$ & $\begin{array}{c}\text { Ref } \\
0.50(0.245,0.99)\end{array}$ & 0.048 \\
\hline $\begin{array}{c}\text { Number of children } \\
\text { None } \\
\text { Any }\end{array}$ & $\begin{array}{l}34(87.2 \%) \\
240(80.8 \%)\end{array}$ & $\begin{array}{c}5(12.8 \%) \\
57(19.2 \%)\end{array}$ & $\begin{array}{c}\text { Ref } \\
1.62(0.60,4.31)\end{array}$ & 0.34 \\
\hline $\begin{array}{r}\text { Years of education } \\
<8 \text { years } \\
>8 \text { years }\end{array}$ & $\begin{array}{l}103(83.7 \%) \\
171(80.3 \%)\end{array}$ & $\begin{array}{l}20(16.3 \%) \\
42(19.7 \%)\end{array}$ & $\begin{array}{c}\text { Ref } \\
1.26(0.70,2.27)\end{array}$ & 0.43 \\
\hline $\begin{array}{c}\text { Monthly income } \\
\text { None } \\
\text { Any }\end{array}$ & $\begin{array}{l}59(74.7 \%) \\
215(83.7 \%)\end{array}$ & $\begin{array}{l}20(25.3 \%) \\
42(16.3 \%)\end{array}$ & $\begin{array}{c}\text { Ref } \\
0.58(0.31,1.06)\end{array}$ & 0.07 \\
\hline $\begin{array}{c}\text { Alcohol use per week } \\
\text { None } \\
\text { Any }\end{array}$ & $\begin{array}{c}247(92.5 \%) \\
27(39.1 \%)\end{array}$ & $\begin{array}{c}20(7.4 \%) \\
42(60.9 \%)\end{array}$ & $\begin{array}{c}\text { Ref } \\
0.47(0.14,1.59)\end{array}$ & 0.22 \\
\hline
\end{tabular}

${ }^{x} \mathrm{CD} 4$ count for HIV infected only

Table 3: Factors associated with positive HBsAg among those with less than 10mlU/ml anti-Hbs titres 36 months' post vaccination $(\mathrm{N}=62)$

\begin{tabular}{|c|c|c|c|c|}
\hline $\begin{array}{l}\text { Characteristics } \\
\mathrm{N}(\%) \text { or mean }(\mathrm{SD})\end{array}$ & $\begin{array}{c}\text { HBsAg positive (n } \\
=7 \text { ) }\end{array}$ & $\begin{array}{l}\text { HBsAg negative } \\
\quad(\mathrm{n}=55)\end{array}$ & OR $(95 \% \mathrm{CI})$ & $\mathrm{P}$ value \\
\hline $\begin{array}{l}\text { HIV status } \\
\text { Uninfected } \\
\text { Infected }\end{array}$ & $\begin{array}{c}0(0 \%) \\
7(14.0 \%)\end{array}$ & $\begin{array}{c}12(100.0 \%) \\
43(86.0 \%)\end{array}$ & $\begin{array}{c}\text { Ref } \\
-\end{array}$ & - \\
\hline $\begin{array}{l}\text { Male } \\
\text { Female }\end{array}$ & $\begin{array}{l}1(5.3 \%) \\
6(14.0 \%)\end{array}$ & $\begin{array}{l}18(94.7 \%) \\
37(86.0 \%)\end{array}$ & $\begin{array}{c}\text { Ref } \\
2.92(0.33,26.10)\end{array}$ & 0.34 \\
\hline $\begin{array}{l}18-30 \text { years } \\
>30 \text { years }\end{array}$ & $\begin{array}{c}23(13.0 \%) \\
4(10.3 \%)\end{array}$ & $\begin{array}{l}20(87.0 \%) \\
35(89.7 \%)\end{array}$ & $\begin{array}{c}\text { Ref } \\
0.76(0.15,3.75)\end{array}$ & 0.74 \\
\hline $\begin{array}{r}\text { CD4 count } \\
<500 \\
>500\end{array}$ & $\begin{array}{c}6(17.6 \%) \\
1(6.3 \%)\end{array}$ & $\begin{array}{l}28(82.4 \%) \\
15(93.7 \%)\end{array}$ & $\begin{array}{c}\operatorname{Ref} \\
0.31(0.03,2.83)\end{array}$ & 0.3 \\
\hline $\begin{array}{c}\text { Number of children } \\
\text { None } \\
\text { Any }\end{array}$ & $\begin{array}{c}0(0 \%) \\
7(12.3 \%)\end{array}$ & $\begin{array}{l}5(100.0 \%) \\
50(87.7 \%)\end{array}$ & $\begin{array}{c}\text { Ref } \\
-\end{array}$ & - \\
\hline $\begin{array}{r}\text { Years of education } \\
<8 \text { years } \\
>8 \text { years }\end{array}$ & $\begin{array}{l}2(10.0 \%) \\
5(11.9 \%)\end{array}$ & $\begin{array}{l}18(90.0 \%) \\
37(88.1 \%)\end{array}$ & $\begin{array}{c}\operatorname{Ref} \\
1.22(0.21,6.89)\end{array}$ & 0.83 \\
\hline $\begin{array}{c}\text { Monthly income } \\
\text { None } \\
\text { Any }\end{array}$ & $\begin{array}{l}5(25.0 \%) \\
2(4.8 \%)\end{array}$ & $\begin{array}{l}15(75.0 \%) \\
40(95.2 \%)\end{array}$ & $\begin{array}{c}\text { Ref } \\
0.15(0.03,0.86)\end{array}$ & 0.03 \\
\hline $\begin{array}{c}\text { Alcohol use per week } \\
\text { None } \\
\text { Any }\end{array}$ & $\begin{array}{l}6(10.2) \\
1(33.3)\end{array}$ & $\begin{array}{l}53(89.8) \\
2(66.7)\end{array}$ & $\begin{array}{c}\text { Ref } \\
4.42(0.35,56.26)\end{array}$ & 0.25 \\
\hline
\end{tabular}




\section{Discussion}

Three years post HBV vaccination almost one in five of the samples from study population did not have adequate protective levels of anti-Hbs titres. We found that eighty percent of those not having protecting anti-Hbs titres were HIV infected individuals. Our findings are similar to others that reported better response to hepatitis $\mathrm{B}$ vaccination among HIV negative persons compared to HIV infected persons ${ }^{(7,13,17)}$. We found a slightly lower response among HIV-1 negative participants compared to other studies that had reported a greater than $95 \%$ sustained of immune response after HBV vaccination among HIV uninfected persons ${ }^{(14)}$. However, these studies assessed immune response at one year. We also observed a higher proportion (72\%) of HIV-infected individuals with protective antibody titres at 3 years compared to other studies $(14,16)$. This is likely due to the booster HBV vaccine given to participants who did not respond to the initial 3-series of HBV vaccination. All participants that received repeat vaccination after having failed the initial series had anti-Hbs titres greater than $10 \mathrm{mlU} / \mathrm{ml}$ (data not shown). Studies have reported improved immune responses and outcomes to hepatitis B vaccine among HIV infected persons who received booster vaccines compared to those who only received an initial 3-dose series of HBV vaccine $^{(4,5,13)}$. Our study found those with low antiHbs titres were HIV infected, had low CD4 count and of female gender. This is similar to other studies conducted in adult African population, which reported gender and low CD4 count as being predictors of poor immune response to hepatitis vaccination $^{(5,16)}$. Interestingly, an earlier study conducted in this cohort, had reported male gender as a predictor of non-response to hepatitis B immune response 6 months post initial HBV vaccination $^{(5)}$. The high risk of incident $\mathrm{HBV}$ infection was found among HIV infected individuals and those who had no income. Low socio-economic status has been associated with increased risk of Hepatitis B infection ${ }^{(2)}$. Our study has demonstrated reduced immune response to HBV vaccination among African HIV infected persons 36 months post vaccination. Our findings can guide policies to develop new vaccination strategies or provide booster vaccines, as well as need for continuous HBV vaccine immune response monitoring among HIV infected people.

\section{Limitations}

A limitation of this study was lack of HIV-1 viral load measurements among HIV infected persons which have also been associated with immune response to $\mathrm{HBV}$ vaccination ${ }^{(5)}$.

In conclusion, we showed that in a cohort of adults there was sustained immune response to hepatitis B vaccine $36-$ month post vaccination among both HIV infected and uninfected participants. However, the reduction in immune response was greater among adults living with HIV infection. Fourteen percent of those with low titres were found to have HBV infection. Due to the waning immune response to hepatitis B vaccine observed in this study, regular evaluation of immune response to $\mathrm{HBV}$ vaccination especially among HIV infected persons and administration of booster doses to those with reduced immunity is recommended.

\section{Acknowledgement}

We thank the Partners PrEP study team and the study funders including Bill and Melinda Gates Foundation; grant numbers OPP47674, HIV serodiscordant couples enrolled at the Partners PrEP Study in Thika, Kenya, for their participation; and the study staff at the Thika Partners Research clinic and the Clinical Trials Laboratory in Nairobi, for their support and contribution to this work.

Financial support. This research study was supported by grant from Kenyatta National Hospital Research and Development Department; grant number KNH/R\&P/23D/45/17.

Potential conflict of interest. All authors report no conflict

Funding: This research study was supported by grant from Kenyatta National Hospital Research and Development Department; grant number $\mathrm{KNH} / \mathrm{R} \& \mathrm{P} / 23 \mathrm{D} / 45 / 17$ 
Reference

1. Sun H-Y, Sheng W-H, Tsai M-S, Lee K-Y, Chang S-Y, Hung C-C (2014). Hepatitis B virus coinfection in human immunodeficiency virus-infected patients: A review. World J Gastroenterol. 2014;20(40): 14598-614.

2. Toukan,A.U, Z.KSharaiha,O.A Hadler, H.S Margolis et.,al (19), The epidemiology of Hepatitis B virus among family members in the middle east. Am J Epidemiol 190; 132-220-32.

3. Kourtis, Bulterys, Hu, Jamieson (2012). HIV-HBV coinfection--a global challenge. N Engl J Med. 2012;366:1749-52.

4. Whitaker JA, Rouphael NG, Edupuganti S, Lai L, Mulligan MJ (2012). Strategies to increase responsiveness to hepatitis $\mathrm{B}$ vaccination in adults with HIV-1. Lancet Infect Dis. 2012;12(12):966-76.

5. Irungu E, Mugo $\mathbf{N}$, Ngure $K$, Njuguna $R$, Celum C, Farquhar C, et al (2012). Immune Response to Hepatitis B VirusVaccination among HIV-1 Infected and Uninfected Adults in Kenya. Infect Diseas. 2012;207.

6. WHO. Hepatitis B 2014. Available from: http//www.who.int/mediacentre/factsheets/fs 204/en/.

7. Uneke, Ogbu, Inyama, Anyanwu, Njoku, Idoko (2005). Prevalence of hepatitis-B surface antigen among blood donors and human immunodeficiency virus-infected patients in Jos,Nigeria. Mem Inst Oswaldo Cruz. 2005;100(1):13-6.

8. Thio (2002). Hepatitis B and human immunodeficiency virus coinfection. Hepatology 2009;49:138-45.

9. Bailey, Smith, Sands (2008). Hepatitis B vaccine: a seven-year study of adherence to the immunization guidelines and efficacy in HIV-1-positive adults. International Journal of Infectious Diseases. 2008;12(6):77-83.
10. EACS European guidelines -v6.0 (2012). Treatment of HIV-positive adults in Europe 2012

11. Geretti, Brook, Cameron, al. e (2008). British HIV Association guidelines for immunization of HIV-infected adults 2008. HIV Med. 2008;9:795-848.

12. Tedaldi, Baker, Moorman (2004). Hepatitis A and B vaccination practices for ambulatory patients infected with HIV. Clin Infect Dis. 2004;38:1478-84.

13. Assad, Francis (1999). Over a decade of experience with a yeast recombinant hepatitis B vaccine. Vaccine. 1999;18:5767.

14. Kim, Harrington, Rompaey V, Kitahata (2008). Independent clinical predictors of impaired response to hepatitis $\mathrm{B}$ vaccination in HIV-infected persons. STD AIDS. 2008;19(9).

15. Mujugira A, Baeten J, Donnell D, al. e.(2011). Characteristics of HIV-1 serodiscordant couples enrolled in a clinical trial of antiretroviral preexposure prophylaxis for HIV-1 prevention. PLoS One. 2011;6.

16. Matthews P, Beloukas A, Malik A, Carlson JM, Jooste P, Ogwu A, et al.(2015). Prevalence and Characteristics of Hepatitis B Virus (HBV) Coinfection among HIV-Positive Women in South Africa and Botswana. PLoS ONE 2015;10(7).

17. Psevdos G, Kim JH, Groce V, Sharp V.(2010). Efficacy of double-dose hepatitis $B$ rescue vaccination in $\mathrm{HIV}$-infected patients. AIDS Patient Care STDS 2010; 24:403-7 